\title{
PROGRAM PENGEMBANGAN KEWIRAUSAHANDI FAKULTAS MATEMATIKA DAN ILMU PENGETAHUAN ALAM (FMIPA) UNIVERSITAS NEGERI MANADO (UNIMA)
}

\author{
Patricia Mardiana Silangen ${ }^{1)}$ \\ ${ }^{1}$ Fakultas Matematika dan Ilmu Pengetahuan Alam \\ Email: silangenpatricia@yahoo.com
}

\begin{abstract}
ABSTRAK
Pelaksanaan Program Pengembangan Kewirausahaan di Fakultas Matematika dan Ilmu Pengetahuan Alam (FMIPA) Universitas Negeri Manado (Unima) bertujuan untuk menumbuh-kembangkan budaya kewirausahaan bagi mahasiswa dalam rangka menciptakan wirausaha mandiri yang berbasis Ipteks. Metode pendekatan dalam pelaksanaan program PPK ini menggunakan model $3 E$ yang mengadopsi Learning Cycle $5 E$ dengan tahapan (1) fase Engage (merasa tertarik untuk menjadi wirausaha) (2) fase Exploration (Eksplorasi dalam berwirausaha-meningkatkan kapasitas sebagai wirausaha), dan (3) fase Establishment (Pelembagaan menjadi wirausaha-menghasilkan wirausaha baru mandiri yang berbasis Ipteks). Target capaian yang rencananya akan diperoleh dari kegiatan PPK FMIPA Unima ini yaitu untuk menghasilkan lahirnya 20 orang mahasiswa FMIPA Unima sebagai wirausaha baru yang dapat menjalankan bisnisnya di berbagai bidang yang berbasis Ipteks. (2) Terwujudnya sistem entrepreneurship bagi mahasiswa FMIPA Unima melalui program PPK ini yang menjalin relasi dengan Unima Humber entrepreneurship centre (UHEC) di bawah payung Lembaga Pengabdian pada Masyarakat Unima.
\end{abstract}

\section{PENDAHULUAN \\ a. ANALISIS SITUASI}

Kata Kunci : Kewirausahaan, Ipteks, Model 3-E, Tenan

Pendidikan adalah modal penting dalam mengarungi perubahan dan perkembangan era modern sekarang ini. Bahkan ada istilah yang menyebut bahwa Pendidikan adalah mata uang yang berlaku di semua negara. Artinya bahwa dengan pendidikan kita sudah mempunyai separuh modal dalam menghadapi tantangan zaman yang semakin pelik, tinggal bagaimana kita mengasah dan mengembangkan potensi yang ada pada diri kita. Setiap orang tentu menginginkan sebuah kehidupan yang layak dan lebih baik. Untuk mewujudkan kehidupan yang layak tersebut adalah dengan mengenyam pendidikan sebagai mana mestinya. Untuk itu Berbagai jenis pendidikan telah dan akan diterapkan diantaranya pendidikan kewirausahaan.

Pendidikan kewirausahaan merupakan kajian internasional terkini dan terus di teliti dan di kembangkan secara dinamis di seluruh belahan dunia. Maraknya pendidikan kewirausahaan di seluruh dunia ini tidak lain karena semakin meningkatnya kesadaran akanpentingnya karakter kewirausahaan pada generasi muda (kreatif, inovatif dan berani mengelola resiko) dan pentingnnya kedudukan seorang wirausaha (entrepreneur) pada motor pergerakan perekonomian suatu negara. Hal ini di jelaskan secara gamblang oleh McClelland bahwa "Negara akan makmur jika entrepreneur dalam suatu negara mencapai $2 \%$ dari keseluruhan penduduknya".(Ade Suyitno : 1)

Direktorat Jendral Pendidikan Tinggi (Dikti) Indonesia sangat sadar akan pentingnya pendidikan kewirausahaan bagi kemajuan sumber daya manusia Indonesia untuk menjawab tantangan masa depan. Oleh karena itu Kementerian Ristek dan Dikti mempunyai program-program unggulan untuk melaksanakan pendidikan kewirausahaan dalam program mahasiswa wirausaha (PMW), Cooperative, Program Kreativitas Mahasiswa Kewirausahaan (PKM-K) dan masih banyak lagi. Hal ini semua di lakukan untuk meningkatkan pengetahuan, niat dan aktivitas kewirausahaan di kalangan mahasiswa.Pendidikan kewirausahaan semakin digalakkan di perguruan tinggi agar mampu menyiapkan mahasiswa untuk berani 
mandiri, tidak lagi terfokus menjadi pencari kerja tetapi mampu menciptakan lapangan kerja bagi diri sendiri dan banyak orang.

Unima sejak tahun 2012 bekerja sama dengan Humber Institute of Technology and Advanced Learning Canada dalam Sulawesi Economic Development Strategy (SEDS) Project yang mengimplemetasikan program kewirausahaan terapan (appliedentrepreneurship) dalam proses pembelajaran telah mengadakan i workshop yang sampai dengan tahun 2016 telah mengadakan 6 workshop kewirausahaan terapan (dengan durasi sekitar 360 jam kerja) untuk 18 dosen kewirausahaan serta serta melalui proyek ini telah didirikan pusat bisnis dengan nama Unima Humber Entrepreneurship Centre (UHEC). Gedung ini diresmikan oleh Duta besar Canada untuk Indonesia dan Rektor Unima pada tanggal 1 Februari 2016. Memiliki 2 ruang administrasi, 1 ruang meeting berkapasitas 20 orang, 5 ruang inkubator bisnis, 1 ruang pelatihan dan pameran berkapasitas 200 orang yang juga dapat dimanfaatkan sebagai ruang inkubator bisnis, 1 unit store untuk display produk dan penjualan, 1 gudang serta toilet.

FMIPA Unima merupakan salah satu dari 7 Fakultas yang ada di Unima dan berlokasi di kabupaten Minahasa Induk provinsi Sulawesi Utara. FMIPA Unima terdiri

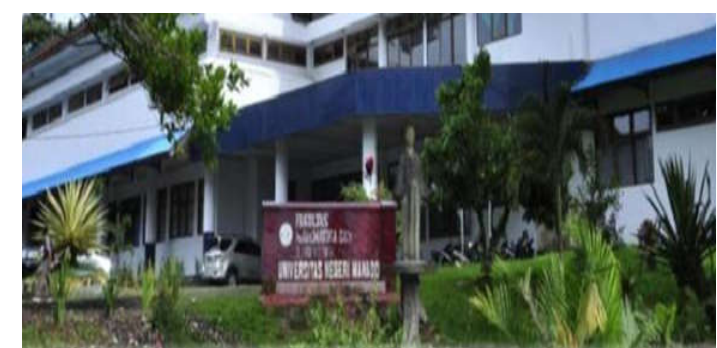

dari 4 jurusan yaitu Matematika, Biologi, Kimia, Fisika dan IPA serta 8 program studi yaitu Pendidikan Matematika, Pendidikan Biologi, Ilmu Biologi, Pendidikan Kimia, Ilmu Kimia, Pendidikan Fisika, Ilmu Fisika dan pendidikan IPA. Mahasiswa FMIPA Unima Tahun Ajaran 2015/2016 berjumlah 3034 mahasiswa dengan Jumlah Mahasiswa untuk masing-masing prodi dapat dilihat pada tabel 1.1 .
Tabel 1.1. Jumlah mahasiswa untuk masing-masing prodi FMIPA Unima Tahun Ajaran 2017/2018

\begin{tabular}{|c|c|c|}
\hline NO. & $\begin{array}{l}\text { PROGRAM } \\
\text { STUDI }\end{array}$ & $\begin{array}{l}\text { JUMLAH } \\
\text { MAHASISWA }\end{array}$ \\
\hline 1 & $\begin{array}{l}\text { Pendidikan } \\
\text { Matematika }\end{array}$ & 1014 \\
\hline 2 & $\begin{array}{l}\text { Pendidikan } \\
\text { Biologi }\end{array}$ & 746 \\
\hline 3 & Ilmu Biologi & 125 \\
\hline 4 & $\begin{array}{l}\text { Pendidikan } \\
\text { Kimia }\end{array}$ & 286 \\
\hline 5 & Ilmu Kimia & 236 \\
\hline 6 & $\begin{array}{l}\text { Pendidikan } \\
\text { Fisika }\end{array}$ & 377 \\
\hline 7 & Ilmu Fisika & 363 \\
\hline \multirow[t]{2}{*}{8} & $\begin{array}{l}\text { Pendidikan } \\
\text { IPA }\end{array}$ & 157 \\
\hline & Jumlah Total & 3034 \\
\hline
\end{tabular}

(Sumber: Puskom Unima 2017)

Salah satu tujuan penyelenggaraan pendidikan di FMIPA Unima adalah Menghasilkan sarjana dan tenaga terdidik yang ahli, terampil, cerdas, mandiri, bermartabat serta profesional di bidang matematika dan sains baik dalam kompetensi kependidikan dan non kependidikan dengan orientasi bahwa lulusan FMIPA Unima dapat bekerja sebagai PNS baik guru maupun non guru serta sebagai karyawan swasta untuk berbagai perusahaan. Pada kenyataan daya serap lulusan untuk suatu pekerjaan sangatlah minim sehingga mahasiswa perlu dibekali dengan pengetahuan kewirausahaan agar pada saat lulus mereka tidak lagi menunggu pekerjaan tetapi dapat menciptakan lapangan kerja menjadi pengusaha. Untuk itulah sejak tahun 2016 pendidikan kewirausahaan terapan 1 dan 2 telah di masukkan dalam kurikulum .

\section{Gambar 1.1.Gedung FMIPA Unima}

\section{METODE PELAKSANAAN}

\section{a. Pola Rekruitmen}

Pola Rekruitmen kegiatan PPK FMIPA Unima melalui tahapan seleksi sebagai berikut :

1. Mensosialisasikan rekrutmen mahasiswa wirausaha 
2. Membuka pendaftaran peserta di awal semester genap berjalan melalui pengisian ormolir yang telah disiapkan

3. Menseleksi calon peserta melalui formolir pendaftaran dan wawancara

4. Mengumumkan peserta yang layak mengikuti kegiatan PPK sebayak 20 mahasiswa

\section{b. Metode Pendekatan}

Metode pendekatan yang akan dilakukan dalam program ini Menggunakan Metode 3-E (Engange, Explore, Establishment) yang mengadopsi Learning Cycle 3-Edengan Prinsip dasar dari metode 3-E adalah pelibatan mahasiswa dalam proses pembelajaran aktif dan demokratis dalam program kewirausahaan (entrepreneurship) secara alamiah dengan segala pendekatan sehingga membentuk suatu sistem interaksi yang terintegrasi.

\section{c. Kolaborasi}

Kegiatan PPK ini berkolaborasi dengan Humber Entreprenuership Centre (UHEC) yang merupakan pusat kewirausahaan di Unima, dan melalui kerjasama ini diiharapkan UHEC akan dapat memberikan kontribusi dengan memfasilitasi berbagai kegiatan kewirausahaan termasuk pameran2 kewirausahaan yang akan diiukuti mahasiswa dalam program PPK ini. Selain UHEC kegiatan PPK ini akan bermitra dengan perusahaan atau instansi yang terkait seperti Bank, Perusahaan-perusahaan industry, dinas koperasi yang diharapkan dapat memberikan kontribusi terlebih dalam rangka kegiatan magang wirausaha, sebagai narasumber/pembekalan dalam pelatihan, memberikan bantuan modal usaha..

\section{d. Persiapan, Pelaksanaan dan Evaluasi PPK}

Persiapan, Pelaksanaan dan Evaluasi PPK ini Berdasarkan pada metode pendekatan untuk tiap fase sebagai berikut

Fase Engage (tahun 1) dengan kegiatan sosialisasi, pelatihan, membuat tim wirausaha, mengikuti pameran di UHEC, Mengikuti seleksi PMW dengan penyelenggara UHEC bekerja sama dengan bagian kemahasiswaan UNIMA. Adapun tahapan dalam fase ini

(1) Pola Sosialisasi dan Rekruitmen Persiapan
1. Menyiapkan materi sosialisasi

2. Membuat formolir pendaftaran calon tenant

3. Menyiapkan instrumen kuesioner yang akan digunakan untuk menyeleksi calon tenant.

4. Menyiapkan tenaga penyeleksi yang akan mewawancarai peserta calon tenant yang sudah melalui seleksi kuesioner.

Pelaksanaan

1. Sosialisasi tentang pengertian umum kewirausahaan dan pentingnya kewirausahaan bagi 100 mahasiswa melalui Ceramah inovatif berbasis multimedia agar mahasiswa tertarik berwirausaha sambil kuliah.

2. Sosialisasi PPK pada Pimpinan FMIPA dan pimpinan-pimpinan jurusan/program studi.

Evaluasi

Evaluasi pelaksanaan kegiatan ini dalam rangka pencapaian tujuan untuk mengukur apakah kegiatan sosialisasi dan rekruitmen ini sudah tepat sasaran atau belum.

(2) Pola Pelatihan

Pola pelatihan mengikuti tahapan sebagaiberikut :

Persiapan

1. Mempersiapkan pemateri baik dari dosen mata kuliah kewirausahaan maupun dari praktisi pengusaha .

2. Mempersiapkan pemateri dari lingkungan internal universitas yang memiliki kompetensi kewirausahaan dosen mata kuliah kewirausahaan atau pemateri dari lembaga yang terkait dengan pelaksanaan PPK yaitu Lembaga Pengabdian kepada Masyarakat.

3. Mempersiapkan jadwal pelatihan

4. Mempersiapkan materi pelatihan dan modul.

5. Kegiatan awal pelatihan adalah Penguatan sosialisasi pada tahap sebelumnya yaitu Penanaman mindset serta attitude kewirausahaan akan dilaksanakan selama 2 (dua) hari dengan berbagai kegiatan metode yang sudah dijalankan oleh pengelola dalam kegiatan kewirausahaan selama ini. Kegiatan ini juga menghadirkan mentor pengusaha muda, utamanya para alumni UNIMA juga pembicara dari tim UHEC.

Pelaksanaan

1. Pelatihan kewirausahaan internal akan di laksanakan di FMIPA minimal 3 jam per 
pertemuan selama 3 bulan dengan volume 2 kali setiap bulan.

2. Pelatihan dengan instruktur eksternal akan dirancang melalui forum pertemuan di pertengahan pelatihan.

3. Pelatihan oleh instruktur eksternal menekankan pada aspek motivasi berwirausaha melalui sharing pengalaman serta belajar dari permasalahan kasus (case based learning) serta pelatihan untuk memperoleh keahlian yang sesuai.

4. Metode pelatihan yang digunakan adalah pelatihan partisipatif yang berorientasi pada keaktifan peserta pelatihan (mahasiswa) diantaranya metode diskusi, brain stroming, dan berbagai meode lainnya yang lebih variati. Pelatihan ini juga akan mengambil suatu tema khusus yang menyesuaikan dengan setiap jenis usaha tenant.

Evaluasi

Evaluasi pelaksanaan kegiatan ini untuk mengukur apakah kegiatan pelatihan ini sudah sesuai dengan kebutuhan tenant atau belum serta mengukur keberhasilan pelaksanaan kegiatan apakah seswuai dengan yang sudah direncanakan dalam mencapai tujuan

Fase Eksplore

Pada fase ini para tenant mulai mengeksplorasikan kemampuan berwirausaha melalui kegiatan sebagai berikut

Melaksanakan Pameran tingkat fakultas

Persiapan

1. Menentukan jadwal pelaksanaan pameran tingkat fakultas

2. Mempersiapkan tempat untuk pameran

3. Membuka pendaftaran untuk seluruh mahasiswa FMIPA

4. Mempersiapkan penilai untuk menilai produk

Pelaksanaan

1. Melaksanakan pameran

2. Menilai peserta yang mengikuti pameran

3. Mengumumkan produk terbaik sesuai kriteria yang ditentukan penilaiiswa/ tenant

Evaluasi

Evaluasi dalam kegiatan ini untuk mengukur antusias mahasiswa dalam mengikuti pameran, serta menilai produk yang di hasilkan mahas

(3) Mengikuti Pameran di UHEC

Persiapan
1. Mengidentifikasi tenant yang sudah memiliki usaha sendiri

2. Merekrut tim kewirausahaan sesuai dengan usaha tenant (max 3 orang)

3. Mempersiapkan produk tenant

Pelaksanaan

1. Mengikuti pameran wirausaha yang dilaksanakan UHEC

2. Menjual hasil produksi wirausaha pada saat pameran di UHEC

Evaluasi

Evaluasi pelaksanaan kegiatan ini untuk mengukur dan menilai/membandingkan produk dengan tenant yang lain tim/fakultas

(4) Mengikuti seleksi PMW

Persiapan

1. Tenant Membuat Proposal Busines plan dengan pengarahan dari tim PPK

2. Merevisi Proposal Busines Plan

Pelaksanaan

1. Memasukan Proposal ke pihak UHEC sebagai penyelenggara seleksi PMW

2. Mengikuti seluruh persyaratan dari penyelenggara

Evaluasi

Evaluasi kegiatan ini sesuai dengan evaluasi yang diselenggarakan pihak penyelenggara

(5) Pola Magang

Persiapan

1. Mempersiapkan mitra berupa peruasahaan/dinas koperasi tempat magang yang siap mengikuti mekanisme magang yang ditentukan pengelola dengan target tertentu.

2. Mempersiapkan wirausaha muda yang akan menjadi mentor dalam magang bagi tenant yang sudah menjalankan usaha.

\section{Pelaksanaan}

1. Kegiatan magang kewirausahaan bagi tenant yang masih dalam tahap ide dan rintisan usaha, akan dilaksanakan dalam bentuk magang di Industri Mitra dengan fokus pada pemahaman business process serta peningkatan kemampuan problem solving atas kegiatan usaha serta manajerial dari suatu usaha. Kemampuan yang didapat dari magang ini akan 
diimplementasikan dalam usahanya sendiri.

2. Bagi Tenant yang sudah memiliki usaha Kegiatan magang bersifat sebagai proses mentoring, di mana magang ini memiliki tujuan agar tenant mampu menemukan alternatif solusi dari permasalahan usaha yang dihadapi. Tenant akan melakukan pengkajian dan pemaparan kepada dosen pembimbing melalui kegiatan focus group discussion, brainstorming dan metaplan. Melalui pengkajian terhadap alternatif solusi dari mentor, diharapkan tenant akan memiliki kemampuan untuk memformulasikan masalah serta mencari jalan keluar terbaik atas permasalahan yang dihadapi di kemudian hari.

3. Kegiatan magang dilaksanakan selama 2 (dua) bulan efektif.

\section{Evaluasi}

Indikator penting yang akan dicapai dalam program magang ini adalah keberhasilan memadukan antara corporate needs dengan rencana pengembangan usaha tenant.

Fase Establishment (tahun 2) dengan tahapan sebagai berikut

(6) Pola Pendampingan

\section{Persiapan}

1. Mempersiapkan materi pendampingan yang terdiri dari data-data awal peserta, apabila yang sudah memiliki usaha data tersebut antara lain laporan keuangan dan laporan perkembangan usaha.

2. Mempersiapkan dosen pendamping yang akan melakukan coaching bisnis.

Pelaksanaan

1. Metode coaching terhadap bisnis adalah suatu program pembimbingan usaha tenant dimana tenant sebagai coachee seolah-olah sedang magang di bisnisnya sendiri dan secara bertahap belajar menerapkan langkah-langkah bisnis di bawah bimbingan coach (pelatih)

2. Keluaran dari proses pendampingan adalah penetapan visi, misi dan budaya bisnis yang menjadi dasar pengelolaan bisnis, kemudian menentukan dan mengevaluasi strategi marketing, pengendalian keuangan, menentukan serta mengevaluasi sistem apa yang diperlukan dalam bisnis baik itu metode rekruitmen tenaga kerja, key performace indicator, ataupun analisa produktivitas.

3. Pada setiap akhir sesi coaching, tenant akan diberikan sejenis tugas yang diberi nama Home Fun. Home Fun berisi tugas terkait dengan materi pembahasan coaching di hari tersebut, sehingga pada pertemuan berikutnya dapat dibahas kemajuan usaha terkait materi yang dibahas.

4. Pertemuan dirancang dalam setiap tatap muka adalah selama minimal 3 (tiga) jam, setiap minggu

5. Dalam program ini coachingakan dilaksanakan selama 8 (delapan) bulan efektif baik untuk tenant yang baru merintis usaha atau bagi yang sudah mengimplementasikan bisnisnya secara nyata.

Evaluasi

Pada setiap akhir sesi coaching, tenant akan diberikan lembar evaluasi yang akan mengevaluasi kualitas coaching pada hari tersebut serta saran dan rekomendasi materi yang diinginkan.

(7) Pembentukan lembaga wirausaha/ koperasi

Persiapan

Mempersiapkan berkas pendirian lembaga

Pelaksanaan

Megurus perizinan lembaga

Evaluasi

Mengevaluasi keberadaan lembaga kewirausahaan di FMIPA

(8) Pengusulan Peminjaman dana di Bank

\section{e. Strategi Pemenuhan Jumlah Peserta 20 tenant/tahun dengan target minimal 5 wirausaha baru /tahun}

Strategi dalam pemenuhan jumlah peserta 20 tenant dengan melakukan pengalokasian komposisi peserta sebagai berikut :

a. Mahasiswa Program PMW: 10 Orang

b. Peserta pameran tingkat fakultas: 5 org

c. Peserta Mahasiswa Rintisan usaha baru : 5 org

\section{f. Pengembangan Unit PPK}

Pengembangan unit PPK ke depan melalui kerjasama dengan berbagai pihak baik internal maupun eksternal terutama di FMIPA Unima : 
1. Berbagai keperluan terkait pelatihan terhadap usaha mahasiswa dan UKM akan menggunakan gedung FMIPA/Jurusan dan gedung UHEC.

2. Secara berkala nantinya para alumni program PPK akan berkumpul bersama dalam forum entrepreneurship sesuai dengan bakat dan kebidangan masingmasing sebagai sarana CSR (Corporate Social Responsibility) untuk mendidik mahasiswa yang sedang memulai usaha baru.

3. Dengan atmosfir kewirausahaan yang baik diharapkan akan muncul jejaring komunitas pengusaha muda yang pada gilirannya akan menjadi bibit yang baik bagi proses pembentukan generasi muda yang mandiri.

4. Secara berkala akan diadakan sharing bisnis.

\section{HASIL PELAKSANAAN}

\section{DESKRIPSI KEGIATAN \\ KEWIRAUSAHAAN DI FMIPA UNIMA}

Program Kewirausahaan Mahasiswa atau mahasiswa berwirausaha Merupakan salah satu indikator keberhasilan suatu perguruan tinggi yang dikeluarkan oleh Kementerian Riset,Teknologi dan Pendidikan Tinggi. Mahasiswa harus dibekali dengan pengetahuan dan ketrampilan berwirausaha sehingga pada saat lulus mereka tidak lagi sebagai Pencari Kerja tetapi mereka sudah memiliki kemampuan berwirausaha yang dapat membuka Lapangan kerja sendiri. Pelaksanaan kegiatan Kewirausahaan yang telah dilaksanakan di FMIPA Unima yaitu Kegiatan Perkuliahan, kegiatan Pameran, Kegiatan Pelatihan dan Kegiatan Pembimbingan.

\subsection{Pelaksanaan Perkuliahan}

Untuk Kegiatan Perkuliahan semua Program studi di FMIPA sudah memasukkan mata kuliah kewirausahaan sebagai mata kuliah wajib denngan bobot SKS antara $2-4$ sks dan dosen kewirausahaan telah mengikuti beberapa wokshop kewirausahaan sehingga memiliki kompetensi untuk mengajar Kewirausahaan. Buku Kewirausahaan yang digunakan memiliki keseragaman dan buku tersebut berasal dari pusat kewirausahaan Unima. Perkuliahan Kewirausahaan dilaksanakan agar mahasiswa merasa tertarik untuk memulai suatu usaha melalui bekal ilmu yang diberikan sehingga mampu mengubah mainset atau pandangan mahasiswa bahwa mereka tidak lagi dididik sebagai pencari kerja pada saat mereka lulus jadi sarjana tetapi mereka harus mampu berwirausaha membuka lapangan pekerjaan sesuai bidang ataupun mampu mengambil suatu peluang sebagai usaha yang menghasilkan. Perkuliahan yang dilaksanakan melalui bernagai metode diantaranya ceramah, diskusi, Brainstorming, telling story, dan tinjauan berbagai kasus yang aplikatif.

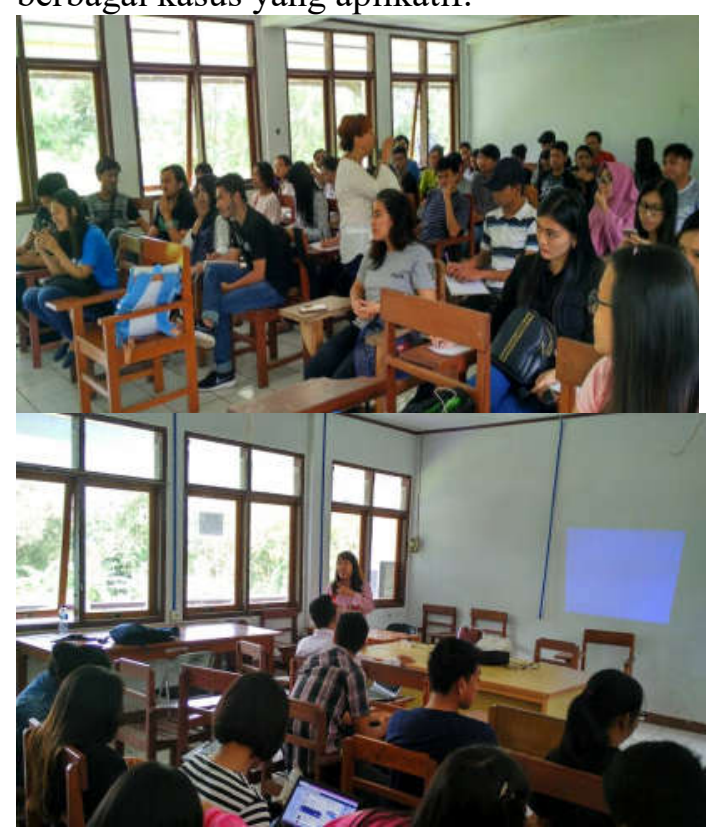

Pelaksanaan Sosialisasi Kewirausahaan pada Mahasiswa baru

Mahasiswa baru perlu diberi pengenalan awal berwirausaha sehingga dilaksanakan sosialisasi awal tentang kewirausahaan yang dilaksanakan di FMIPA mengawali perkuliahan mahasiswa baru. 


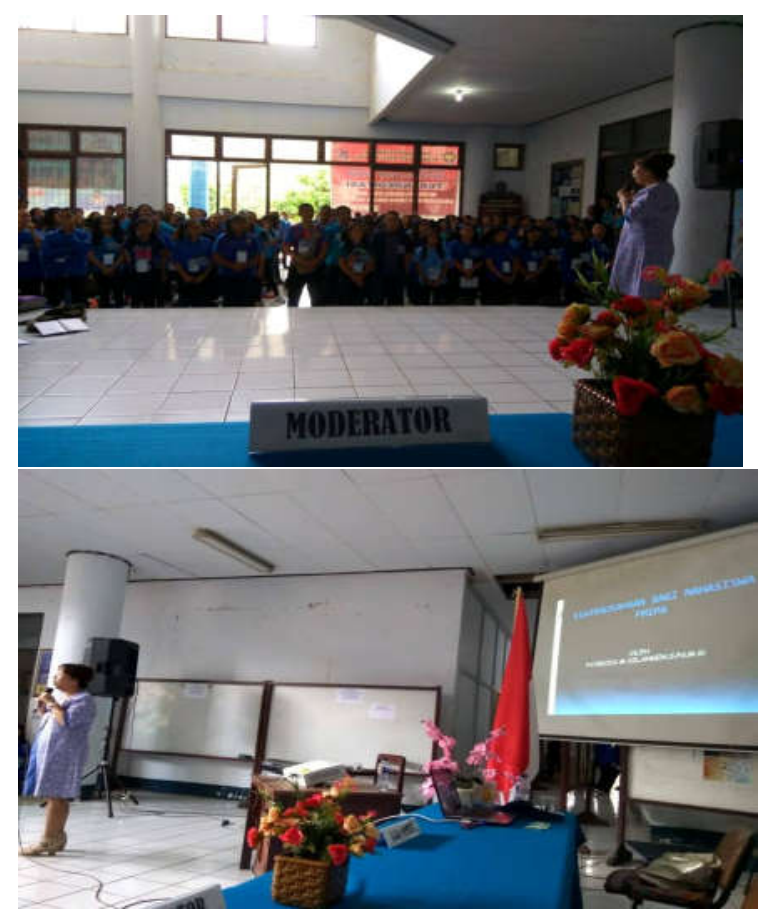

\section{Pelaksanaan Pameran}

Mahasiswa yang telah berwirausaha mengikuti pameran kewirausahaan yang dilaksanakan di Unima dengan pelaksana UHEC. Banyak Mahasiswa FMIPA yang megikuti kegiatan Pameran ini.

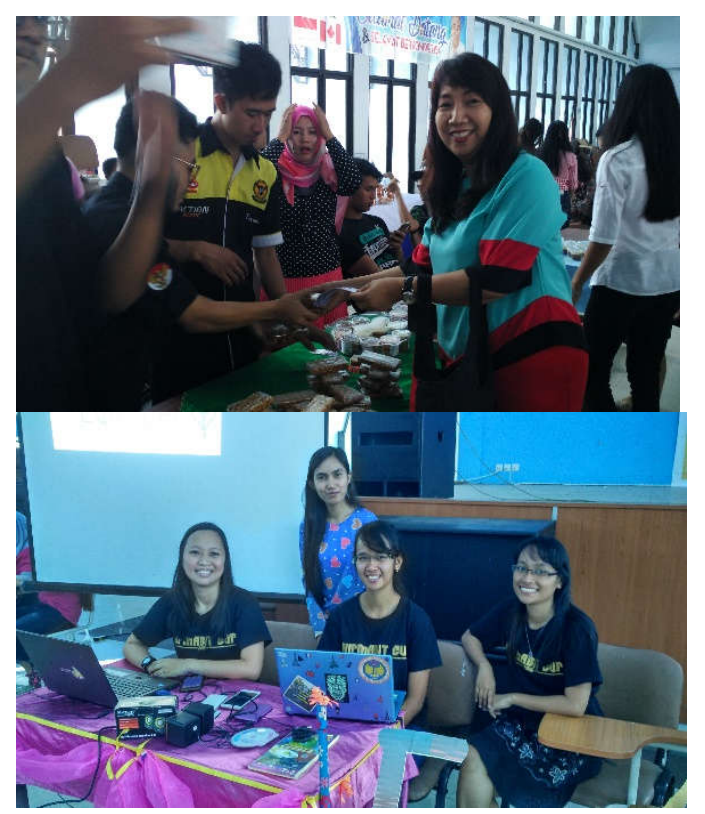

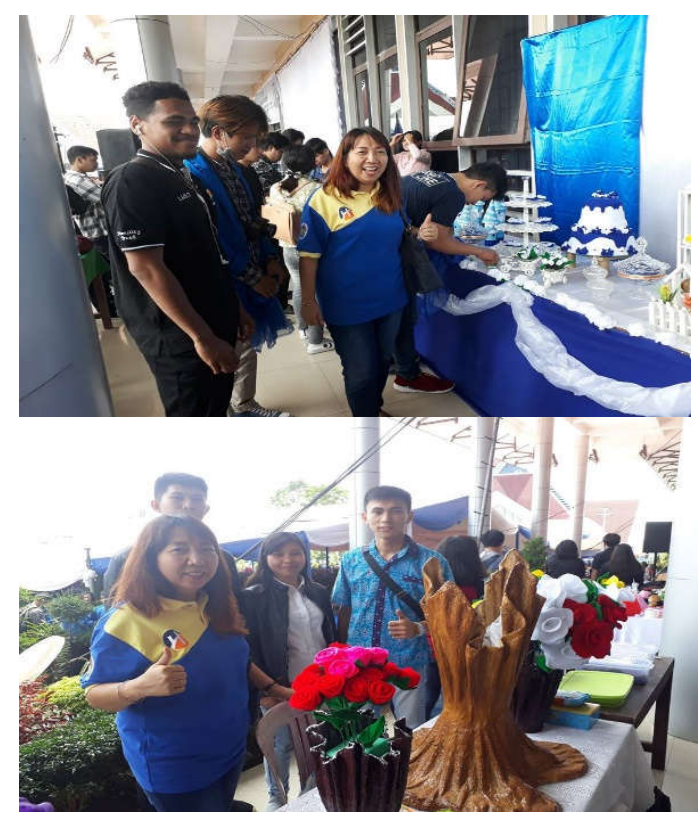

Pelaksanaan Pembimbingan

Mahasiswa yang berwirausaha terus dibimbing dan dalam kegiatan bimbingan ini mahasiswa melakukan sharing usaha yang telah mereka lakukan serta masalah-masalah yang mereka hadapi untuk ditemukan solusinya.

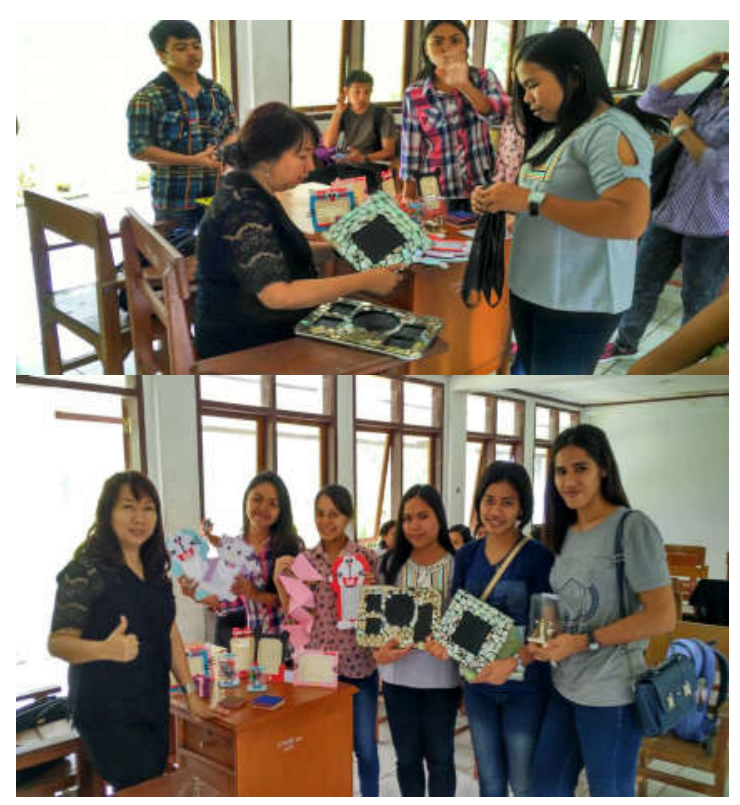

Pelaksanaan Pelatihan

Pelatihan yang telah di jalankan dalam kegiatan kewirausahaan ini yaitu

Pelatihan tentang Green entreprenuer .Metode yang digunakan dalam pelatihan ini adalah Cerama, Diskusi, Praktek, Demonstrasi dan Belajar sambil bermain 


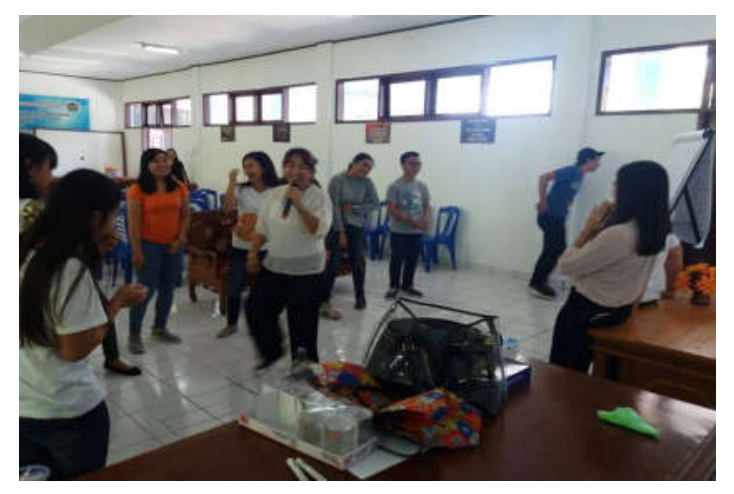

\section{PENUTUP}

\section{a. KESIMPULAN}

Kegiatan Kewirausahaan yang telah dikembangkan di Fakultas Matematika dan Ilmu Pengetahuan Alam telah terlaksana dengan kegiatan Perkuliahan Kewirausahaan, Brain: A Fun and Fascinating Approach to Understanding Yourself And Others. Thorofare: Slack Inc.

Hisrich, R. D., Peters, M. P., \& Shepherd, D. A. 2010. Entrepreneurship. McGraw-Hill.

Hisrich, R. D. \& Peters, M. P. 1995. Entrepreneurship. Starting. Developing. and Managing A New Entreprise. New York: .

Kotler, P. 2000. Marketing Management, Millenium Edition. Tenth Edition. Prentice-Hall.

Kuwayama, Y. 1973. Trade Marks and Symbols. New York: Van Nostrand Reinhold Inc. .

Odiorne, G. S. 1984. Strategic management of human resources. Jossey-Bass.

Robbins, S. P. \& Coulter, M. 2002. Management (activebook). 7 th ed. Prentice Hall.

Susanto, A. B. 2007.Corporate Social Responsibility. Jakarta: The Jakarta Consulting Group.

Weston, J. F., dkk. 1995. Manajemen Keuangan. Edisi 9, Jilid 1. Jakarta: Bina Rupa Aksara.

World Intellectual Property Organisation (WIPO). 2008. Membuat Sebuah Merek, Pengantar Merek Untuk Usaha Kecil dan Menengah. Terjemahan KADIN Indonesia.
Sosialisasi, Pelatihan, Pembimbingan, Pameran.

\section{b. SARAN}

Kegiatan kewirausahaan memerlukan dukungan dari berbagai pihak dari pimpinan institusi, Fakultas, Jurusan/Prodi.

\section{REFERENSI}

Bybee, R. W., Taylor, J. A., Gardner, A., Scotter, P. V., Powell, J. C., Westbrook, A., \& Landes, N. 2006. The BSCS 5E instructional model: Origins and effectivenessDrucker, P.1996. Inovasi dan Kewirausahaan Praktek dan Dasar-dasar. Jakarta: Erlangga.

Glazov, S. N. 2007. What Color is Your 